\title{
Development of Learning Materials Criticism of Art Based Criticism Culture
}

\author{
Tri Aru Wiratno, Diana Nomida Musnir, Atwi Suparman, Jhoni Lagun Siang
}

\begin{abstract}
The development of learning materials for critical culture-based art critics in the Art Criticism program at the Fine Arts Study Program, Faculty of Fine Arts, Jakarta Arts Institute was used to improve the ability of students and lecturers in the learning process about art criticism. By developing learning materials, critics of art based on critical culture, make the learning process reach its goals. Students and lecturers will work together in the learning process. Students know and understand the stages of learning carried out, while the lecturer knows and understands in learning for students with material learning critical art based criticism of culture. The research method conducted using Borg and Gall, the development of learning materials using procedural Dick and Carey learning models. By identifying instructional objectives, conducting intrudional analysis, student analysis, writing performance goals, developing assessment instruments, developing instructional strategies, developing and selecting instructional materials, formative instructional design and evaluation, revising instructions, designing and conducting summative evaluations. The results of the research on the development of learning materials based on critical culture-based art critics are expected to increase the ability and awareness of art as a reflection of his life.
\end{abstract}

Keywords: Development of Learning Materials, Criticism of Art, Critical Culture

\section{INTRODUCTION}

The problem that occurred in the lecture on fine arts criticism in IKJ Pure Arts was that there were no learning material books. And less interested in students reading art books and books related to art. Art criticism is a shutter which has wider possibilities in the artistic process more conceptually. It is a critique of art as an activity and practice to analyze and critique elements of line art, color, sweep, shape, field, composition and space. Based on that expression, art in the activities of work takes place in the form of art works, and at the same time there is a reflection of the problems revealed in works of art. The critique of reflection art itself is a form of internalization of works of art in an awareness, understanding, contemplation and thought of the theme of the problem and the practice of creating

Revised Manuscript Received on September 22, 2019.

Tri Aru Wiratno, Post Graduation Departmen of Educational Technology Universitas Negeri Jakarta and Lecturer at Universitas Kristen Indonesia Maluku. triaruwiratno@yahoo.co.id

Diana Nomida Musnir, Professor at Universitas Negeri Jakarta. diananomida@gmail.com

Atwi Suparman, Profesor at Universitas Terbuka Indonesia. atwisuparman@ut.ac.id

Jhoni Lagun Siang, Teacher at SMP Negeri 11 Tidore Kepulauan. jhonilagunsiang@yahoo.co.id painting. Delivering on the pratek dimension of art that is not in art, but the art practice that encourages exploring arts thinking, conceptual art, as well as exploring art media that provide an understanding of art errors and socio-cultural realities of society.

Art criticism is able to develop an understanding of all kinds of media in a process to be able to explore the forms of art without limits. Art criticisms can be made using approaches and methods of writing that allow art to be better understood and appreciated. This is done in art criticism, an activity and practice of development and research on a work of art, using and procedural works by using research methods in a broad sense. As a mirror and reflective of the sociocultural reality in the development of massive technology and information. The critique of art activities explored becomes a reflection, internalization of problems and art practice activities with technological developments and informing them to be integrated into a research concept.

Critics of art provide knowledge in the practice of working art about ideas, attitudes and art. It can also be a concept of knowledge and development as the awareness of students in art critics lectures, which provides new insights into the practice of creating art by using other possibilities. As a form of reflection in art critics and art practice activities, the second provides knowledge and concepts of art criticism. For this reason, research on the Development of Critical Lecture in Art has become interesting for the lecture process of art criticism as a view in the concept of art and the practice of artwork. The extent to which the views on the Development of Lecture Materials Criticism of art are something new, and the extent to which the practice of art works, art critics see this using a research approach.

\section{LITERATURE REVIEW}

\section{A. Learning Materials Art Critics Based on Critical Culture Fine}

Arts education makes painting a part of art. The aim was published by the 2007 Ministry of National Education's Directorate General of Higher Education which is now the Ministry of Education and Culture. The content of the purpose of learning art is to understand and master painting well.

A graduate of fine arts must have the main competencies, namely basic competencies and personality, study competence, creation competency, skill competency and work behavior, and other competencies. Thus, the

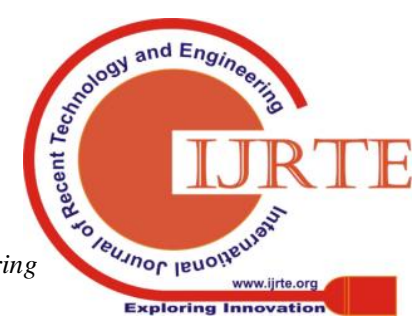


purpose of education in the field of art is as follows.

- Able to express ideas or ideas in the form of works of art;

- Able to account for his work ethically, morally and academically and have supporting competencies;

- Able to study and analyze various art and cultural phenomena;

- Able to respond to the existence of archipelago art with broad insight and knowledge that enables them to make cross-linkages between local, national and international cultures; and

- Having attitudes and behavioral patterns that uphold artistic ethics and scientific behavior as art graduates. culture as a control and guidance in the times. (Academic Signs of Indonesian Arts Higher Education, 2007: 4-5)

Development of learning materials for pure arts students must pay attention to the criteria for developing learning materials, as stated by Rowntree: 1) good structure, 2) clear learning goals, 3) arranged in small learning units, 4) involving students (students) in learning, 5) complete, 6) having repetition, 7) allowing students to synthesize learning material, 8) encouraging learning processes, 9) varying in delivering, 10) allows students to adapt, 11) have feedback, and 12) have a continuous evaluation. ( Derek Rowntree, 1994: 122-123).

\section{Methodology/Materials}

This research focuses on research on the development of lectures in art critics in Fine Arts students, the Faculty of Fine Arts, Jakarta Arts Institute. The approach or research design used was a qualitative approach with the $\mathrm{R} \& \mathrm{D}$ method Dick and Carey modified the research and development methods of Borg and Gall. In qualitative research data or information is obtained described in the form of literature studies, observations, interviews, and documentation.

Borg and Gall define research and development as follows.

Research and development is an industry based development model in which the findings are used to design new products and procedures which are systematically tested, evaluated, and similar criteria of effectiveness, quality, or similar standards. (Borg Walter R. Gall Meredith, Gall Joyce, 2007: 589.)

Research and development is an industry-based development model in which research findings are used to design new products and procedures, then systematically tested in the field, evaluated, and refined to meet certain criteria of effectiveness, quality, or the same standard.

The developer was able to make a contribution to instructional strategy into other phases of the target audience's educational programs. The results of this pilot test on student performance skills and perceived self-efficacy. (Borg Walter R. Gall Meredith, Gall Joyce, 2007: 594.)

In the case of the $\mathrm{R} \& \mathrm{D}$ project described above, development was able to contribute to the education practice of a colleague and suggested future R \& D efforts to develop valuable learning strategies into other phases of the target student education program. The results of this trial contribute new knowledge and raise new questions, about the effects of problem-based learning on students' performance abilities and can be felt by themselves.

Based on the opinions above, it can be concluded that the research on the Development of Art Critical Lecture Materials with a deductive approach is a process used to develop and validate products used in education. Products produced by learning models in learning material products are guidelines in Critical Arts lectures.

Thus, from these products can be produced Critical Art and innovative able to develop self-existence so that they are able to have care and be critical of socio-cultural problems. As a way to be more precise in accordance with what becomes a learning goal, Critical Arts wants to be achieved rather than being a critical student.

\section{Results AND Findings}

Results of the research on the development of learning materials critics of critical culture-based art became the beginning of learning in the subject of art criticism. Contributing to the development of art, because critics are based on critical culture based on IKJ's pure art study program as a paradigm shift in the thinking of art lecturers. Lecturers need knowledge about learning design as a foundation for teaching gradually and sustainably. The results of this development research can be applied adaptively.

The results of this research and development of learning materials based on critical culture based on art critics can be used as the development of fine art thinking, to improve the ability of lecturers to teach painting material in lectures. One of the students at the end made critical writings critically as a good learning process to achieve effective and efficient learning in delivering learning objectives.

The results of research and development in addition to producing learning materials critical culture-based art critics are also equipped with guidelines for lecturers and student guidance to be used by lecturers and students in the lecture process. With this learning material students understand the learning material learned. The research begins with preliminary research, namely by conducting observations and collecting information and data about lectures in the course of painting which is described in stages.

The results of the research on the development of learning materials carried out in the Critical Art lecture material produced designs and materials learning based on the identification of problems related to students, curriculum, syllabus, and lecture material that uses power points was developed by making learning materials in the form of printed material as learning material for critical culture-based art criticism.

The results of the research on the development of learning materials criticizing critical culture-based art became the beginning of learning in the subject of Art Criticism, IKJ's pure art study program as a paradigm shift in the thinking 
of art lecturers. Lecturers need knowledge about learning design as a foundation for teaching gradually and sustainably. The results of this development research can be applied adaptively.

The results of research and development of learning materials critical culture-based art critics can be used as learning to improve the ability of lecturers to teach Fine Arts Criticism lecture material. One of the students at the end of the lecture made critical art writing as a good learning process to achieve effective and efficient learning in delivering learning objectives.

The results of research and development in addition to producing learning materials critical culture-based art critics are also equipped with learning materials, guidelines for lecturers and student guidance to be used by lecturers and students in the lecture process. With this learning material students understand the learning material learned.

The research begins with preliminary research, namely by observing and gathering information and data about lectures in the subject of art criticism which is described in stages.

\section{A. Discussion}

Based on research on students and lecturers in the Pure Arts Study Program, this research was conducted using the approach of researcher involvement and observation by involving it in the lecture process in Fine Arts Study Program. The lecture on Critical Art was carried out with an approach to the curriculum and syllabus. The learning process in lectures in art criticism is a process of transforming information from lecture material provided by lecturers in lectures. Thus, the learning process in the lecture of art criticism is not yet on the achievement of what is called the process of learning objectives.

For this reason, this study has identified learning and analysis of learning in learning in art criticism, to arrive at making learning mixtures and draft learning materials.

During the lecture process students are taught critical culture-based art critics based on their art knowledge and competence of lecturers, not based on the appropriate learning method. The task of making critical culture-based art critics is given by an inductive approach that deals with the form of directly viewing exhibitions and attending exhibitions in both the opening and discussion of fine arts.

Information and data are obtained in learning methods and learning competencies, as a lecture process for a lecturer. Completeness prepared from curriculum planning to conducting learning in critical culture-based art criticism lectures. When organizing learning art critics is still simple, there are no lecturers who understand and do learning design learning.

\section{Conclusion}

Development of learning materials critical culture-based art critics in art criticism courses become part of an academic culture in constructing the knowledge of art as a critique of art, as a process of developing lecturers' knowledge in making art criticism learning materials, making lectures able to develop in developing art knowledge in line with development knowledge and development of art knowledge by lecturers.

Learning materials of critical culture-based art critics also provide students with learning abilities in accordance with their abilities in a reflective and critical manner as a culture of criticism that develops within themselves in the lecture process that they participate in. Making learning in art critics lectures, students develop according to their respective abilities, according to their sincerity in attending art critics lectures.

For this reason, the research and development of art criticism courses produce results, as follows:

- Design learning materials in subjects of art criticism

- Making learning material in critical culture-based subjects of art criticism

\section{ACKNOWLEDGEMENTS}

This research work is supported by the Jakarta State University.

\section{REFERENCES}

[1] Agger, Bem. 2008. Critical Social Theories: An Introduction Diterjemahkan Teori Sosial Kritis: Kritik, Penerapan, dan Implikasinya.

[2] Bahari Nooryan, Cetak ke III 2017. Kritik Seni, Yogyakarta; Pustaka Pelajar

[3] Borg, Walter R., Gall Meredith, dan Gall Joyce P. 2007. Education Research. United State of America: Penerbit Person.

[4] Bujono Bambang, Wicaksono Adi. 2012. Seni Rupa Indonesia Dalam Kritik dan Esai. Jakarta, Dewan Kesenian Jakarta.

[5] Bujono Bambang, Apresiasi Seni Rupa Indonesia;Esai Kritik Dan Suwaryono, Jakarta; FSR IKJ Press

[6] Bahari Nooryan.2017. Kritik Seni; Wacana Apresiasi dan Kreasi. Yogyakarta, Pustaka Pelajar

[7] Bangun Sem C. 2001. Kritik Seni Rupa. Bandung, Penerbit ITB

[8] Bujono Bambang. 2015. Esai dan Kritik Dan Suwaryono. Jakarta, FSR IKJ

[9] Bujono Bambang. 2017. Melampaui Citra dan Ingatan. Jakarta, Yayasan Jakarta Biennale

[10] Dick, Walter dan Carey. 2009. The Systematic Design of Instruction. , United States of America: Pearson.

[11] Gagne Robert M. 1990, Kondisi Belajar dan Teori Pembelajaran (Jakarta: Departemen Pendidikan dan Kebudayaan Direktorat Jenderal Pendidikan Tinggi,

[12] http://bahanajarpendidikan.blogspot.com/

[13] Iswantara Nur, 2016. Kritik Seni, Seni Kritik, Yogyakarta;Gigih Pustaka Mandiri

[14] Kusrianto, Adi dan Made Arini. 2011. Histoy of Art. Jakarta: Elex Media Komputindo.

[15] Marianto, M. Dwi. 2006. Quantum Seni. Semarang: Dahara Prize.

[16] Marianto, M. Dwi. 2015. Art dan Levitation. Yogyakarta: Pohon Cahaya.

[17] Mamanoor, 2002. Wacana Kritik Seni Rupa Di Indonesia, Bandung; Nuansa

[18] Rahmin Maghfur M. 2017. Teori Kritis Filsafat Lintas Mazhab. Yogyakarta Sociality

[19] Rambu-rambu Akademik Pendidikan Tinggi Seni Indonesia" 2007. Jakarta: Direktorat Akademik, Direktrorat Jenderal Pendidikan Tinggi Departemen Pendidikan Nasional

[20] Rowntree Derek, 1994. Teaching Through Self Instruction: How to Develop Open Learning Materials. London: Kogan Page

[21] Suparman, Muhammad Atwi. 2015. Panduan Para Pengajar dan Inovator Pendidikan: Desain Instruksional Modern. Jakarta: Erlangga.

[22] Susanto, Mike. 2011. Diksi Seni Rupa. Bali: Jagad Art Space

[23] Supangkat, Jim. 2012. Srihadi and Art in Indonesia. Jakarta: Art 1 New Museum

[24] Tri Priyatni Endah, Nurhadi,2017. Membaca dan Literasi Kritis Tangerang, Tira Smart 
[25] Wiratno, Tri Aru. 2017. Seni Lukis, Konsep dan Metode, Tangerang, personal.

\section{AUTHORS PROFILE}

My name is Tri Aru Wiratno, I am working as lecturer in Post Graduation Department of Educational Technology Universitas Negeri Jakarta and Lecturer at Universitas Kristen Indonesia Maluku. My area of interest is social sciences.

I am Diana Nomida Musnir, I am working as Professor at Universitas Negeri Jakarta. My area of interest is social sciences.

My name is Atwi Suparman, I am Profesor at Universitas Terbuka Indonesia. My area of research is social sciences

My name is Jhoni Lagun Siang, I am working as Teacher at SMP Negeri 11 Tidore Kepulauan. My area of interest is social sciences. 